\title{
Development of Duck Diseases Expert System with Applying Alliance Method at Bali Provincial Livestock Office
}

\author{
Dewa Gede Hendra Divayana \\ Chairman of Information Technology Department \\ Faculty of Computer, Indonesia Technology University \\ Bali, Indonesia
}

\begin{abstract}
Farming is one of the activities that have a business opportunity. One is raising ducks. The main results can be obtained from the breeding duck is a duck meat and eggs for consumption and also means praying ceremony in Bali, as well as duck egg shells that can be used for jewelry. Since the outbreak of avian influenza began in 2008, have an impact on consumer demand of ducks decreased and consumers become more careful in choosing and consuming duck. The avian influenza virus not only spread across the country of China, Thailand and Vietnam, but also in Indonesia, Bali is no exception. This is evidenced by the discovery of cases of death due to bird flu virus in some areas in Bali, among others: the regency of Karangasem, Badung, Tabanan, Klungkung and Jembrana. From this, the Bali Provincial Livestock Office took steps to develop an expert system in the detection of diseases ducks. This expert system uses a alliance method is a combination of forward chaining, backward chaining and weighted product to search the physical symptoms and behavioral symptoms duck by the name of a known disease and to determine the percentage of disease attack level in ducks. In this study, the analytical techniques used to analyze the truth is a alliance method of duck disease expert system. Activity data collection and information to support research conducted by, among others, literature studies, interviews, and observations.
\end{abstract}

Keywords-Expert System; Forward Chaining; Backward Chaining; Weighted Product; Alliance Method; Duck Diseases

\section{INTRODUCTION}

Farming is one of the activities that have a business opportunity. One is raising ducks. Raising ducks is one business that can be used as a promising source of income for most people in Indonesia and Bali in particular. Besides the cheap price of the seed, maintenance of duck also not as difficult as raising pigs or cows. It is shown from the results of research conducted Bali Provincial Livestock Office that shows the average demand for duck meat increased by $30 \%$ each year and is followed by the rise of the merchant ducks in some areas in Bali.

The main results can be obtained from the breeding duck is a duck meat and eggs for consumption and also means praying ceremony in Bali, as well as duck egg shells that can be used for jewelry.

From some of the advantages and benefits gained from raising ducks, of course there are also the challenges or obstacles faced duck breeders include overcoming disease in ducks. In fact, since the outbreak of avian influenza in the 2008-2012 year range ducks impact on demand from consumers has decreased and consumers become more careful in choosing and consuming duck.

The avian influenza virus not only spread across the country of China, Thailand and Vietnam, but also in Indonesia, Bali is no exception. This is evidenced by the discovery of cases of death due to avian influenza virus in some areas in Bali, among others: the regency of Karangasem, Badung, Tabanan, Klungkung and Jembrana.

Therefore, the community needs to know what are the types of diseases that can be contracted on a duck. With the importance of knowledge about the types of the duck disease, it is deemed necessary to provide a medium that can provide information about diseases in ducks. As for some of the media that may be obtained easily is through magazines, newspapers, television broadcasts, radio broadcasts, educational and training organized by the Bali Provincial Livestock Office, can also even through the computerized system.

The computerized system is an expert system to duck diseases detection. Duck diseases expert system have ability to ducks diseases detect and analyzed in detail.

\section{LITERATURE REVIEW}

\section{A. Expert Systems}

In [1], Expert Systems is a branch of Artificial Intelligence that makes extensive use of specialized knowledge to solve problems at the human expert level.

In [2], an expert system is the computer system that emulates the behaviour of human experts in a wellspecified manner, and narrowly defines the domain of knowledge. It captures the knowledge and heuristics that an expert employs in a specific task. An overview of current technologies applied with an expert system that is developed for Database Management System, Decision Support System, and the other Intelligent Systems such as Neural Networks System, Genetic Algorithm, etc.

In [3], an Expert system is a software that simulates the performance of a human experts in a specific field. Today's 
expert systems have been used in many areas where require decision making or predicting with expertise.

In [4], the Expert System (ES) is one of the well-known reasoning techniques that is utilized in diagnosis applications domain. In ES, human knowledge about a particular expertise to accomplish a particular task is represented as facts and rules in its knowledge base [4].

From the definitions of the above can be concluded in general that expert systems is an artificial intelligence system that combines knowledge base with inference engine so that it can adopt the ability of the experts into a computer, so the computer can solve problems such as the often performed by experts.

\section{B. Forward Chaining}

The inference engine contains the methodology used to perform reasoning on the information in the knowledge base and used to formulate conclusions. Inference engine is the part that contains the mechanism and function of thought patterns of reasoning systems that are used by an expert. The mechanism will analyze a specific problem and will seek answers, conclusions or decisions are best. Because the inference engine is the most important part of an expert system that plays a role in determining the effectiveness and efficiency of the system. There are several ways that can be done in performing inference, including the Forward Chaining. In [5], forward chaining is matching facts or statements starting from the left (first IF).

\section{Backward Chaining}

Also in [5], backward chaining is matching facts or statements starting from the right (first THEN). In other words, the reasoning starts from the first hypothesis, and to test the truth of this hypothesis to look for the facts that exist in the knowledge base.

\section{Weighted Product}

In [6], Weighted Product Method (WP) use multiplication to connect the attribute ratings, where the ratings of each attribute must be raised first with the relevant attribute weights. This process is similar to the process of normalization. Preferences for alternative $\mathrm{Ai}$ is given as follows:

$$
S_{i}=\prod_{j=1}^{n} x_{i j}{ }^{w_{j}} \quad \text { with } \mathrm{i}=1,2, \ldots, \mathrm{n} \text { and } \mathrm{w}_{\mathrm{j}}=1
$$

$\mathrm{w}_{\mathrm{j}}$ is the power of positive value to attribute profits, and is negative for the cost attribute. Relative preference of each alternative, given as:

$$
V_{i}=\frac{\Pi_{\mathrm{j}}^{\mathrm{n}}=1 x_{i j}{ }^{{ }^{w}}}{\Pi_{\mathrm{j}}^{\mathrm{n}}=1\left(x_{j^{*}}\right)^{w_{j}}} \quad \text { with } \mathrm{i}=1,2, \ldots, \mathrm{n}
$$

$\mathrm{V}$ : Preferences alternatives considered as a vector $\mathrm{V}$

$\mathrm{X}$ : Value of Criteria

w : Weight of Criteria / Sub-criteria

i : Alternative

j : Criteria

$\mathrm{n}$ : number of criteria

\section{E. Alliance Method}

In [7], stated that Alliance method is a combination of forward chaining, backward chaining and weighted product to search the name of the disease based on symptoms or vice versa as well as to determine the percentage of disease provided by the users of the system (user) and the expert.

\section{METHODOLOGY}

\section{A. Object dan Research Site}

1) Research Object is Expert System of Duck Diseases With Applying Alliance Method.

\section{2) Research Site at Bali Province Livestock Department.}

\section{B. Data Type}

In this research, the authors use primary data, secondary data, quantitative data and qualitative data.

\section{Data Collection Techniques}

In this research, the authors use data collection techniques such as observation, interviews, and documentation.

\section{Analysis Techniques}

Analysis techniques used in this research is descriptive statistical.

\section{RESULT AND DISCUSSION}

\section{A. Result}

\section{1) Early Trial}

At this early trial, the authors conducted a limited scale testing of the duck diseases expert system that have been made previously by involving five staff of Bali Provincial Livestock Office to perform white box and black box testing. This test can be done by giving 10 questionnaires early trials duck disease expert systems to staff of Bali Provincial Livestock Office. Diagram form of answers score percentage given by the respondents in early trial can be described as follows:

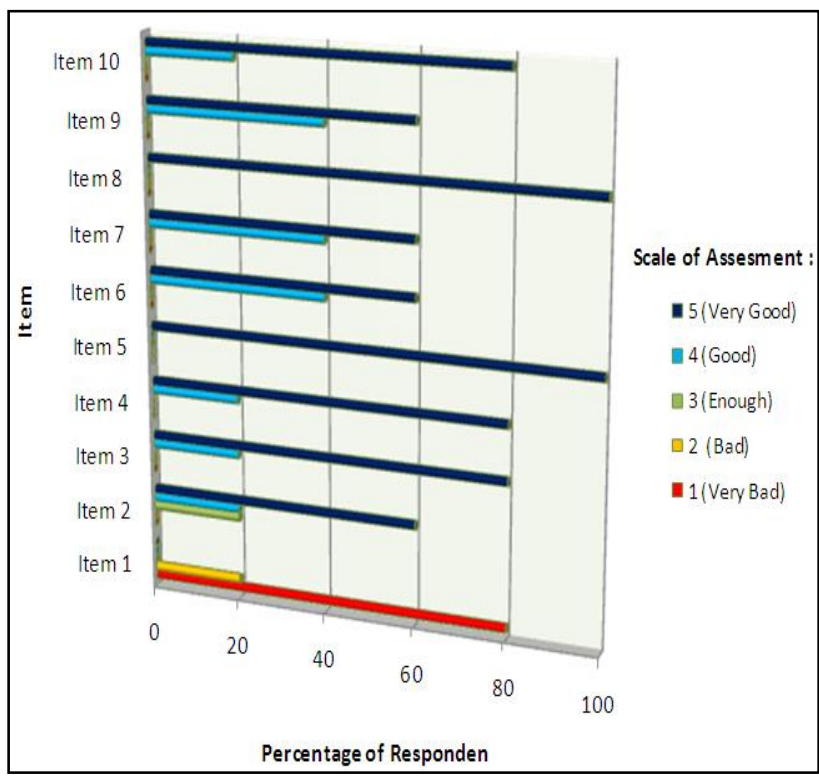

Fig. 1. Percentage Diagram of Respondents Answer Score In Early Trial 
Based on the diagram above, it can be seen that the results of early trials of the duck disease expert system, find a constraint that is the answer to a very bad score by $80 \%$ of the questions on the questionnaire $1^{\text {st }}$ initial trials. This is due to the unavailability of the form for the manufacture of a new username and password in the future if there is a mutation of the staff who operate the duck disease expert system. Given these constraints, then the system needs to be revised again.

\section{2) Field Trial}

At this field trial, the authors tested in a larger scale, involving an expert (vet) is understood about the duck diseases and seven staff of Bali Provincial Livestock Office. This test can be done by giving 16 questionnaires field trials duck disease expert systems to the vet and the staff of the Bali Provincial Livestock Office.

Diagram form of answers score percentage given by the respondents in field trial can be described as follows:

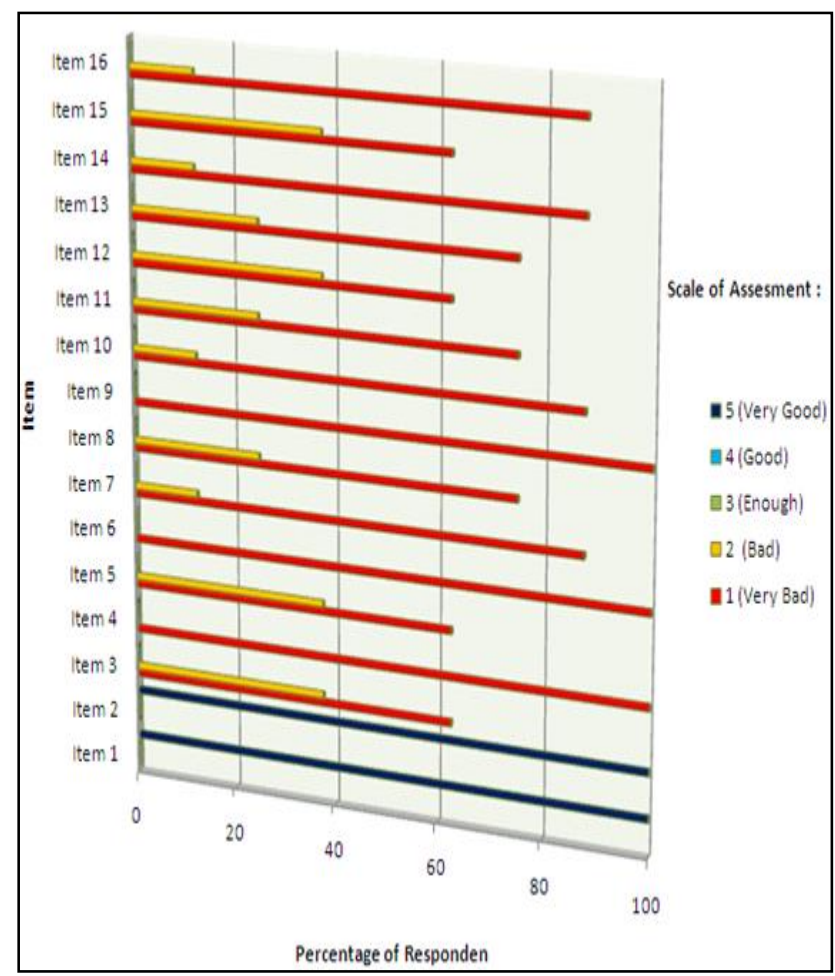

Fig. 2. Percentage Diagram of Respondents Answer Score In Field Trial

Based on the diagram above, it can be seen that the results of a field trial of the duck diseases expert system, the presence of obstacles that scores are very bad answer the score of $62.5 \%$ to the question $3^{\text {rd }}, 5^{\text {th }}, 12^{\text {th }}$, and $15^{\text {th }}, 75 \%$ of the questions $8^{\text {th }}, 11^{\text {th }}$ and $13^{\text {th }}$, at $87.5 \%$ of the questions $7^{\text {th }}, 10^{\text {th }}$, $14^{\text {th }}$, and $16^{\text {th }}$, and at $100 \%$ of the questions $4^{\text {th }}, 6^{\text {th }}$ and $9^{\text {th }}$ on field trial questionnaire.

This is due to the unavailability of the form to enter or edit the physical symptoms and behavioral symptoms duck if in the future there is a new symptom on the physical and behavior of ducks, as well as the unavailability of the form to enter or edit the rule, and the weight of duck disease attack rate.
Of the constraints are found, then the system needs to be revised to obtain duck disease expert systems more interactive and dynamic.

\section{3) Usage Test}

At this usage test, the authors conducted a trial involving with the use of 20 people (breeder duck). The test is performed to test the operation of the overall form available on duck diseases expert system that has undergone revisions to field trials. This test can be done by giving the user satisfaction questionnaire to the expert system diseases duck to duck breeders who visited Bali Provincial Livestock Office.

Diagram form of answers score percentage given by the respondents in usage test can be described as follows:

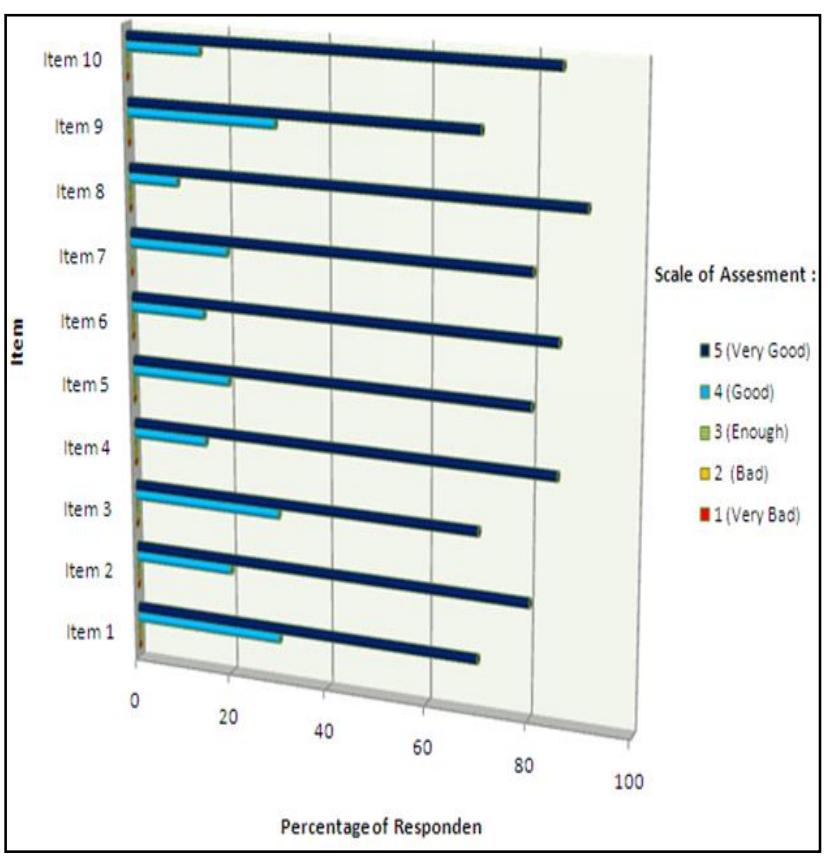

Fig. 3. Percentage Diagram of Respondents Answer Score In Usage Test

Based on the diagram above, it can be seen that the results of testing the use of the duck diseases expert system outline already looks very good and not found again the constraints in terms of technical operation (inputing and editing a new symptom on the physical and behavioral duck) as well as the principle method of expertise (alliance method). This is evidenced by the percentage scoring very good response by $70 \%$ of statements $1^{\text {st }}, 3^{\text {rd }}$, and $9^{\text {th }}$.

Percentage scoring very good response by $80 \%$ against the statement of the $2^{\text {nd }}, 5^{\text {th }}$, and $7^{\text {th }}$. Percentage scoring very good response by $85 \%$ of statements $4^{\text {th }}, 6^{\text {th }}$, and $10^{\text {th }}$. As well as scoring $90 \%$ of the questions on the questionnaire $8^{\text {th }}$ trial usage. And it would be even better if the duck diseases expert system added amenities help programs written in accordance with the suggestions of the respondents to the improvement of the system, so as to explain the performance of the expert system and the function of the buttons in the design of an duck diseases expert system overall with easy to understand and simple language. 


\section{B. Discussion}

1) Shows alliance method has been run according to the rules

In analyzing the validity of this method alliance rule, the author will check the compatibility between the results obtained from the trial decision table rule forward chaining, backward chaining and weighted product made by respondents to the decision table rules forward chaining and backward chaining, and the results of the calculation of weighted existing product the duck diseases expert system program. As for the decision table forward chaining rules and backward chaining as well as the results of the calculation of weighted products that exist in the duck diseases expert system and table test program conducted by the respondent and can be explained as follows:

a) Forward chaining and backward chaining rules decision table of duck diseases expert system

TABLE I. FORWARD CHAINING AND BACKWARD CHAINING RULES OF DUCK DISEASES EXPERT SYSTEM

\begin{tabular}{|c|l|c|c|c|c|}
\hline \multirow{2}{*}{ No } & \multirow{2}{*}{$\begin{array}{c}\text { The } \\
\text { Sympto } \\
\text { ms }\end{array}$} & \multicolumn{4}{|c|}{ Name of Diseases } \\
\hline & $\begin{array}{c}\text { Avian } \\
\text { Influenza }\end{array}$ & $\begin{array}{c}\text { Duck } \\
\text { Cholera }\end{array}$ & $\begin{array}{c}\text { Salmo } \\
\text { nelosis }\end{array}$ & $\begin{array}{c}\text { Botulis } \\
\text { mus }\end{array}$ \\
\hline . & Fur & & & & \\
\hline a & Moult & $\sqrt{ }$ & - & $\sqrt{ }$ & - \\
\hline b & Dull & - & $\sqrt{ }$ & - & $\sqrt{ }$ \\
\hline $\mathbf{2 .}$ & Wing & & & & \\
\hline a & Hanging & $\sqrt{ }$ & - & $\sqrt{ }$ & - \\
\hline b & Moult & - & $\sqrt{ }$ & - & $\sqrt{ }$ \\
\hline $\mathbf{3 .}$ & Foot & & & & \\
\hline a & Limp & $\sqrt{ }$ & - & - & $\sqrt{ }$ \\
\hline b & Swelling & - & $\sqrt{ }$ & $\sqrt{ }$ & - \\
\hline $\mathbf{4 .}$ & Dirt & & & & \\
\hline a & $\begin{array}{l}\text { Watery } \\
\text { Yellow }\end{array}$ & - & - & $\sqrt{ }$ & $\sqrt{ }$ \\
\hline b & $\begin{array}{l}\text { Watery } \\
\text { White }\end{array}$ & $\sqrt{ }$ & $\sqrt{ }$ & - & - \\
\hline $\mathbf{5 .}$ & Behavior & & & & \\
\hline a & $\begin{array}{l}\text { Often rub } \\
\text { the head } \\
\text { to the } \\
\text { ground }\end{array}$ & $\sqrt{ }$ & - & - & - \\
\hline b & $\begin{array}{l}\text { Stand } \\
\text { with one } \\
\text { leg }\end{array}$ & - & - & - & $\sqrt{ }$ \\
\hline c & $\begin{array}{l}\text { Often } \\
\text { sleepy }\end{array}$ & - & $\sqrt{ }$ & - & - \\
\hline d & Totter & - & - & $\sqrt{ }$ \\
\hline
\end{tabular}

b) Analyze the calculation correctness of the weighted product method in duck disease expert systems

To check the calculation correctness of this weighted product method done several things, among others:

- Determination of the weight of each physical and behavioral symptoms of ducks were observed by the user, the attack rate and weight values include: low attack rate with weight value $=0.25$, enough attack with weight value $=0.50$, high attack with weight value $=0.75$, and very high attack with weight value $=$ 1.

- Determination of the weight of each physical and behavioral symptoms of ducks were observed by experts, the attack rate and weight values include: low attack rate with weight value $=0.10$, enough attack with weight value $=0.20$, high attack with weight value $=0.30$, and very high attack with weight value $=$ 0.40 .

- Seeking percentage duck disease attack rate by multiplying the weight of all the results of powers between the physical and behavioral duck symptoms observed by user to weight the physical and duck behavioral symptoms observed by expert. And the results of these calculations multiplied by $100 \%$.

For example:

- The weight data of every physical and behavioral symptoms of ducks were observed by the user are as follows:

TABLE II. WEIGHT DATA FROM USER OBSERVATION

\begin{tabular}{|c|l|c|l|}
\hline Duck & \multicolumn{1}{|c|}{$\begin{array}{c}\text { Physical } \\
\text { Symptoms }\end{array}$} & Weight & \multicolumn{1}{|c|}{$\begin{array}{c}\text { Attack } \\
\text { Level }\end{array}$} \\
\hline \multirow{4}{*}{ A } & Fur & 0.5 & Enough \\
\cline { 2 - 4 } & Wing & 0.75 & High \\
\cline { 2 - 4 } & Foot & 0.5 & Enough \\
\cline { 2 - 4 } & Dirt & 0.25 & Low \\
\cline { 2 - 4 } & Behavior & 0.5 & Enough \\
\hline \multirow{4}{*}{ B } & Fur & 1 & Very High \\
\cline { 2 - 4 } & Wing & 0.75 & High \\
\cline { 2 - 4 } & Foot & 0.5 & Enough \\
\cline { 2 - 4 } & Dirt & 0.25 & Low \\
\cline { 2 - 4 } & Behavior & 0.75 & High \\
\hline \multirow{4}{*}{ C } & Fur & 0.5 & Enough \\
\cline { 2 - 4 } & Wing & 1 & Very High \\
\cline { 2 - 4 } & Foot & 0.5 & Enough \\
\cline { 2 - 4 } & Dirt & 0.75 & High \\
\cline { 2 - 4 } & Behavior & 0.5 & Enough \\
\hline
\end{tabular}

- The weight data of every physical and behavioral symptoms of ducks were observed by the expert are as follows:

TABLE III. WEIGHT DATA FROM EXPERT OBSERVATION

\begin{tabular}{|c|c|c|c|}
\hline Duck & $\begin{array}{c}\text { Physical } \\
\text { Symptoms }\end{array}$ & Weight & $\begin{array}{c}\text { Attack } \\
\text { Level }\end{array}$ \\
\hline \multirow{5}{*}{ A } & Fur & 0.2 & Enough \\
\hline & Wing & 0.3 & High \\
\hline & Foot & 0.2 & Enough \\
\hline & Dirt & 0.1 & Low \\
\hline & Behavior & 0.2 & Enough \\
\hline \multirow{5}{*}{ B } & Fur & 0.4 & Very High \\
\hline & Wing & 0.3 & High \\
\hline & Foot & 0.2 & Enough \\
\hline & Dirt & 0.1 & Low \\
\hline & Behavior & 0.3 & High \\
\hline \multirow{5}{*}{$\mathrm{C}$} & Fur & 0.2 & Enough \\
\hline & Wing & 0.4 & Very High \\
\hline & Foot & 0.2 & Enough \\
\hline & Dirt & 0.3 & High \\
\hline & Behavior & 0.2 & Enough \\
\hline
\end{tabular}

- From these data it can be searched percentage of duck disease attack rate in the following way:

- S Vector to duck-A : 
$\mathrm{S}-\mathrm{A}=\left(0.5^{0.2}\right) *\left(0.75^{0.3}\right) *\left(0.5^{0.2}\right) *\left(0,25^{0.1}\right) *\left(0.5^{0.2}\right)=0.526859$

- S Vector to duck-B :

$\mathrm{S}-\mathrm{B}=\left(1^{0.4}\right) *\left(0.75^{0.3}\right) *\left(0.5^{0.2}\right) *\left(0.25^{0.1}\right) *\left(0.75^{0.3}\right)=0.637712$

- $\mathrm{S}$ Vector to duck-C :

$\mathrm{S}-\mathrm{C}=\left(0.5^{0.2}\right) *\left(1^{0.4}\right) *\left(0.5^{0.2}\right) *\left(0.75^{0.3}\right) *\left(0.5^{0.2}\right)=0.605202$

Then the $\mathrm{S}$ vector of the results that have been obtained above, then:

- The percentage rate of the disease in duck-A is $=0.526859 * 100 \%=52.69 \%$

- The percentage rate of the disease in duck-B is $=0.637712 * 100 \%=63.77 \%$

- The percentage rate of the disease in duck-C is $=0.605202 * 100 \%=60.52 \%$

c) Trials alliance method performed by respondents

Respondents who did this trial was a veterinarian as experts and seven staff Bali Provincial Livestock Office conducted the field trials. The trial results are shown in the following table.

TABLE IV. TRIALS ALLIANCE METHOD

\begin{tabular}{|c|c|c|c|c|c|c|c|c|c|c|c|c|}
\hline \multirow{3}{*}{$\begin{array}{c}\text { Respon } \\
\text { dent }\end{array}$} & \multicolumn{8}{|c|}{ Physical Evidence } & \multirow{2}{*}{\multicolumn{2}{|c|}{ Behavior }} & \multirow{3}{*}{ DS } & \multirow{3}{*}{$\begin{array}{l}\% \\
\mathbf{A} \\
\mathbf{L}\end{array}$} \\
\hline & \multicolumn{2}{|c|}{ Fur } & \multicolumn{2}{|c|}{ Wing } & \multicolumn{2}{|c|}{ Foot } & \multicolumn{2}{|c|}{ Dirt } & & & & \\
\hline & $\mathbf{S}$ & $\begin{array}{l}\mathbf{A} \\
\mathbf{L}\end{array}$ & $\mathbf{S}$ & $\begin{array}{l}\mathbf{A} \\
\mathbf{L}\end{array}$ & $\mathbf{S}$ & $\begin{array}{l}\mathbf{A} \\
\mathbf{L}\end{array}$ & $\mathbf{S}$ & $\begin{array}{l}\mathbf{A} \\
\mathbf{L}\end{array}$ & $\mathbf{S}$ & $\begin{array}{l}\mathbf{A} \\
\mathbf{L}\end{array}$ & & \\
\hline RS.01 & $\begin{array}{l}\mathrm{F} \\
1\end{array}$ & $\mathrm{E}$ & $\begin{array}{c}\mathrm{W} \\
1\end{array}$ & $\mathrm{H}$ & $\begin{array}{l}\mathrm{T} \\
1\end{array}$ & $\mathrm{E}$ & $\begin{array}{l}\mathrm{D} \\
2\end{array}$ & $\mathrm{~L}$ & B1 & $E$ & $\mathrm{AI}$ & $\begin{array}{c}52 . \\
69\end{array}$ \\
\hline RS.02 & $\begin{array}{l}\mathrm{F} \\
2\end{array}$ & $\mathrm{~V}$ & $\begin{array}{l}\mathrm{W} \\
2\end{array}$ & $\mathrm{H}$ & $\begin{array}{l}\mathrm{T} \\
2\end{array}$ & $\mathrm{E}$ & $\begin{array}{l}\mathrm{D} \\
2\end{array}$ & $\mathrm{~L}$ & B3 & $\mathrm{H}$ & $\mathrm{DC}$ & $\begin{array}{l}63 . \\
77\end{array}$ \\
\hline RS.03 & $\begin{array}{l}F \\
2\end{array}$ & $\mathrm{E}$ & $\begin{array}{l}\text { W } \\
2\end{array}$ & $\mathrm{~V}$ & $\begin{array}{l}\mathrm{T} \\
1\end{array}$ & $\mathrm{~L}$ & $\begin{array}{l}\mathrm{D} \\
1\end{array}$ & $\mathrm{E}$ & B2 & $\mathrm{L}$ & $\mathrm{BL}$ & $\begin{array}{l}57 . \\
43\end{array}$ \\
\hline RS.04 & $\begin{array}{l}\mathrm{F} \\
1\end{array}$ & $\mathrm{~L}$ & $\begin{array}{c}\mathrm{W} \\
1\end{array}$ & $\mathrm{~L}$ & $\begin{array}{l}\mathrm{T} \\
2\end{array}$ & $\mathrm{~L}$ & $\begin{array}{l}\mathrm{D} \\
1\end{array}$ & $\mathrm{H}$ & B4 & $\mathrm{L}$ & SL & $\begin{array}{l}52 . \\
69\end{array}$ \\
\hline RS.05 & $\begin{array}{l}\mathrm{F} \\
1\end{array}$ & $\mathrm{~V}$ & $\begin{array}{c}\mathrm{W} \\
1 \\
\end{array}$ & $\mathrm{~V}$ & $\begin{array}{l}\mathrm{T} \\
1 \\
\end{array}$ & V & $\begin{array}{l}\mathrm{D} \\
2\end{array}$ & $\mathrm{~V}$ & B1 & $\mathrm{H}$ & $\mathrm{AI}$ & $\begin{array}{l}91 . \\
73 \\
\end{array}$ \\
\hline RS.06 & $\begin{array}{l}\mathrm{F} \\
1\end{array}$ & $\mathrm{H}$ & $\begin{array}{c}\mathrm{W} \\
1 \\
\end{array}$ & $\mathrm{E}$ & $\begin{array}{l}\mathrm{T} \\
2 \\
\end{array}$ & $\mathrm{H}$ & $\begin{array}{l}\mathrm{D} \\
1 \\
\end{array}$ & $\mathrm{E}$ & B4 & $\mathrm{E}$ & SL & $\begin{array}{l}55 . \\
52 \\
\end{array}$ \\
\hline RS.07 & $\begin{array}{l}\mathrm{F} \\
2\end{array}$ & $\mathrm{~L}$ & $\begin{array}{c}\mathrm{W} \\
2\end{array}$ & $\mathrm{~L}$ & $\begin{array}{l}\mathrm{T} \\
1\end{array}$ & $\mathrm{H}$ & $\begin{array}{l}\mathrm{D} \\
1\end{array}$ & $\mathrm{~V}$ & $\mathrm{~B} 2$ & $\mathrm{~V}$ & $\mathrm{BL}$ & $\begin{array}{l}69 . \\
52\end{array}$ \\
\hline RS.08 & $\begin{array}{l}\mathrm{F} \\
2\end{array}$ & $\mathrm{H}$ & $\begin{array}{l}\mathrm{W} \\
2 \\
\end{array}$ & $\mathrm{E}$ & $\begin{array}{l}\mathrm{T} \\
2 \\
\end{array}$ & V & $\begin{array}{l}\mathrm{D} \\
2\end{array}$ & $\mathrm{H}$ & B3 & $\mathrm{V}$ & DC & $\begin{array}{l}73 . \\
25 \\
\end{array}$ \\
\hline
\end{tabular}

Explanation :

S : Symptoms

AL : Attack Level

F1 : Moult

DS : Name of Diseases

F2 : Dull

W1 : Hanging

$\%$ AL : Percentage of Attack Level W2 : Moult

L : Low

E : Enough

$\mathrm{H}$ : High

$\mathrm{V} \quad$ : Very High

AI : Avian Influenza

DC : Duck Cholera

BL : Botulismus

SL : Salmo nelosis

T1 : Limp

T2 : Swelling

D1 : Watery Yellow

D2 : Watery White

B1 : Often rub head to the ground

B2 : Stand with one leg

B3 : Often sleepy

B4 : Totter

Based on the table results of trials alliance method performed respondents mentioned above, it can then be analyzed by comparing the results of Table IV with rule tables owned by duck diseases expert systems (Table I) were applied to the Bali Provincial Livestock Office.

The results of the matches between the two tables can be analyzed that the alliance method has been run in accordance with the rules. This is evidenced by the correspondence between the code and the calculation of the percentage of symptom attack rate obtained by testing respondents and based on the existing rules in an expert system that generates the name of the disease which is also in accordance with the rules.

To view the alliance method has been run in accordance with the rules can be seen in the percentage diagram of response trials suitability rules.

Answer percentage diagram form of rules conformance testing given by the respondents can be described as follows:

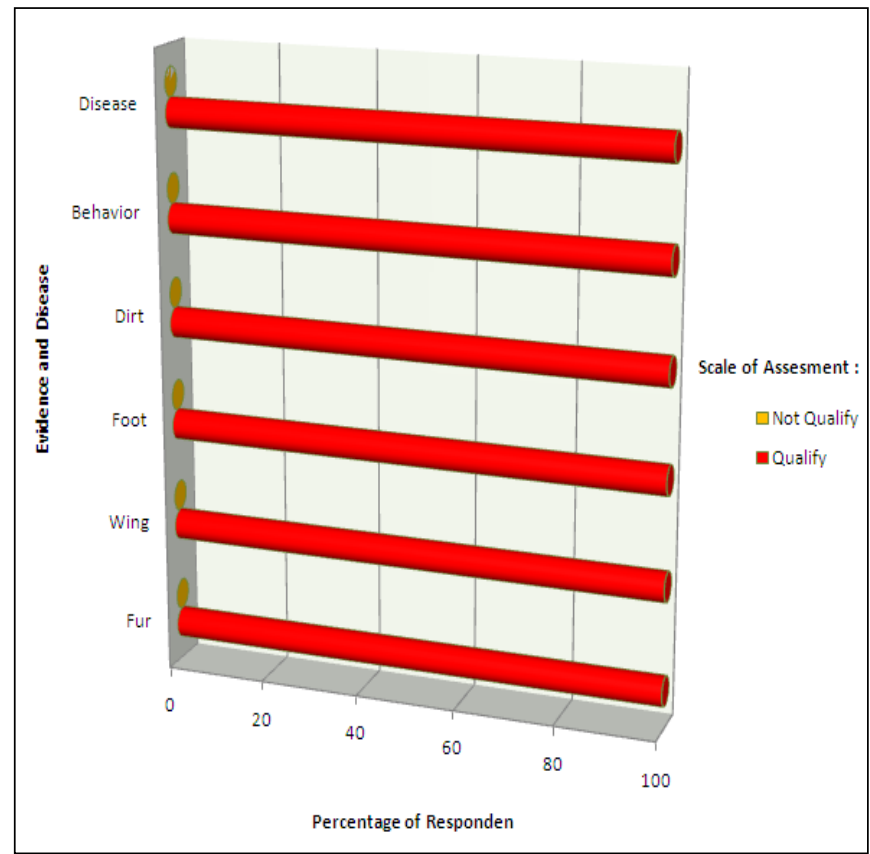

Fig. 4. Answer Percentage Diagram of Rules Conformance Testing

Based on the diagram above, it can be seen that the results of testing the suitability of duck diseases expert system rules is an outline already looks qualify. This is evidenced by the percentage of the answer symptoms fur, wing, foot, dirt, behavior and disease name according to the rules in the field of testing and each get a percentage of $100 \%$.

2) Implementation of Duck Diseases Expert System a) Login Form

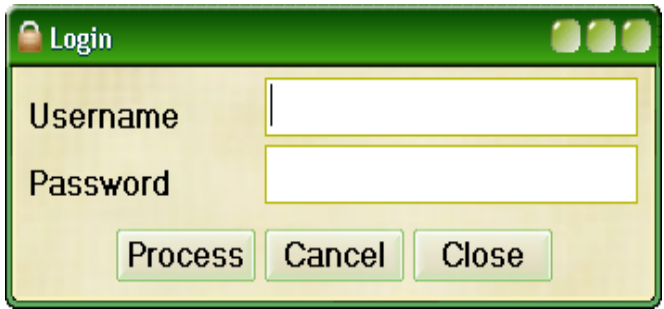

Fig. 5. Login Form

This login form is used by staff of Bali Provincial Livestock Office to be able to come into main menu form, especially to activate of master menu, search, and report found on duck diseases expert system. 


\section{b) Main Menu Form}

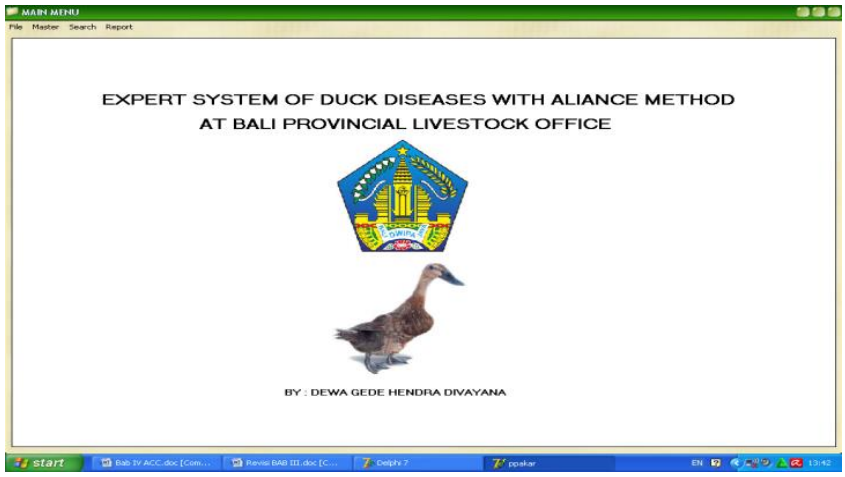

Fig. 6. Main Menu Form

This main menu form used as link to file menu, master, search, and report.

\section{c) Membership Registration Form}

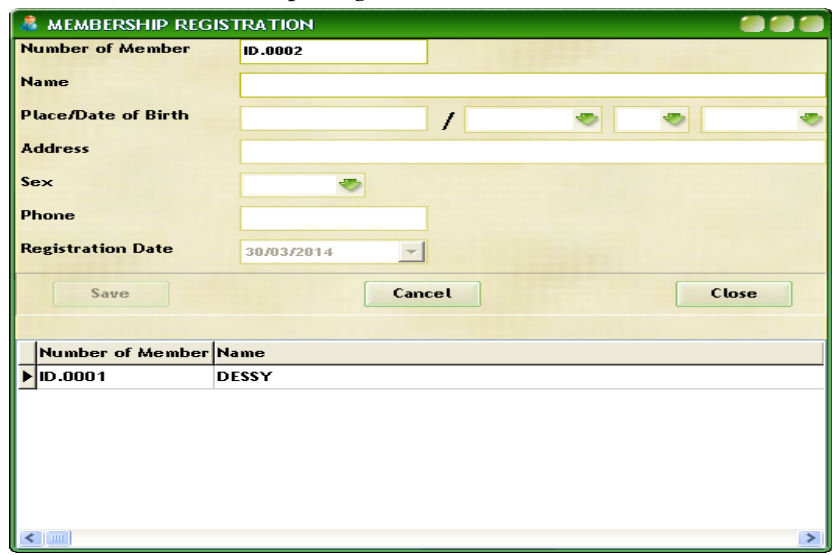

Fig. 7. Membership Registration Form

Membership registration form is used as registration facility of incoming member looking for information about duck diseases.

\section{d) Duck Diseases Data Input Form}

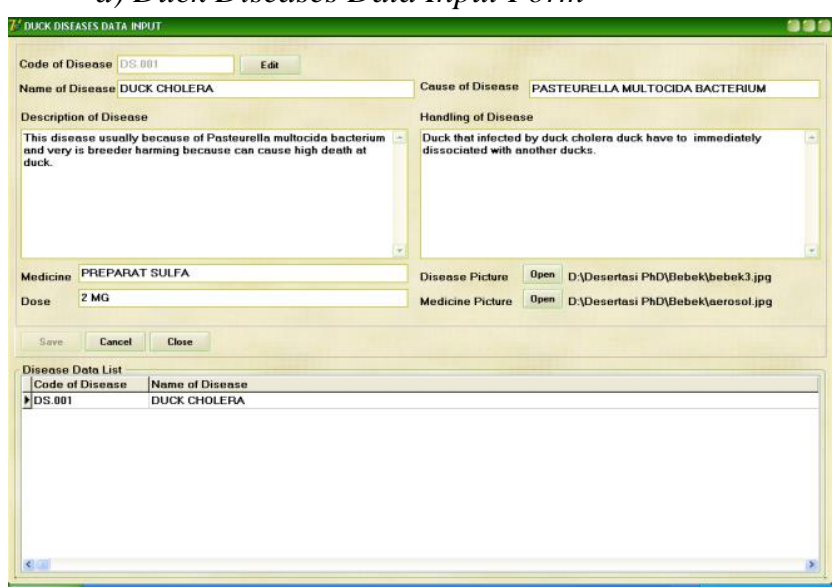

Fig. 8. Duck Diseases Data Input Form

Duck diseases data input form is used by staff of Bali Provincial Livestock Office to enter detail explaination about duck diseases. e) Symptoms Data Input Form

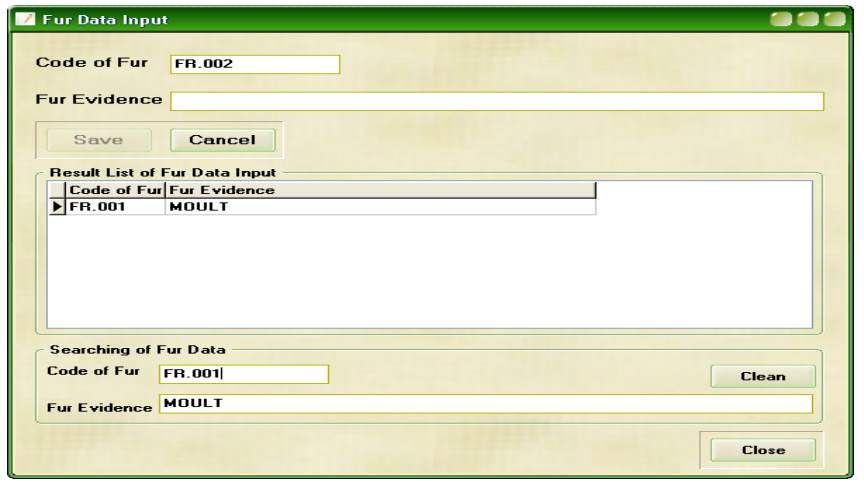

Fig. 9. Symptoms Data Input Form

This symptoms data input form can be used for the input of new symptom for the fur, wing, foot, dirt, and behavior symptoms.

\section{f) Rules Data Input Form}

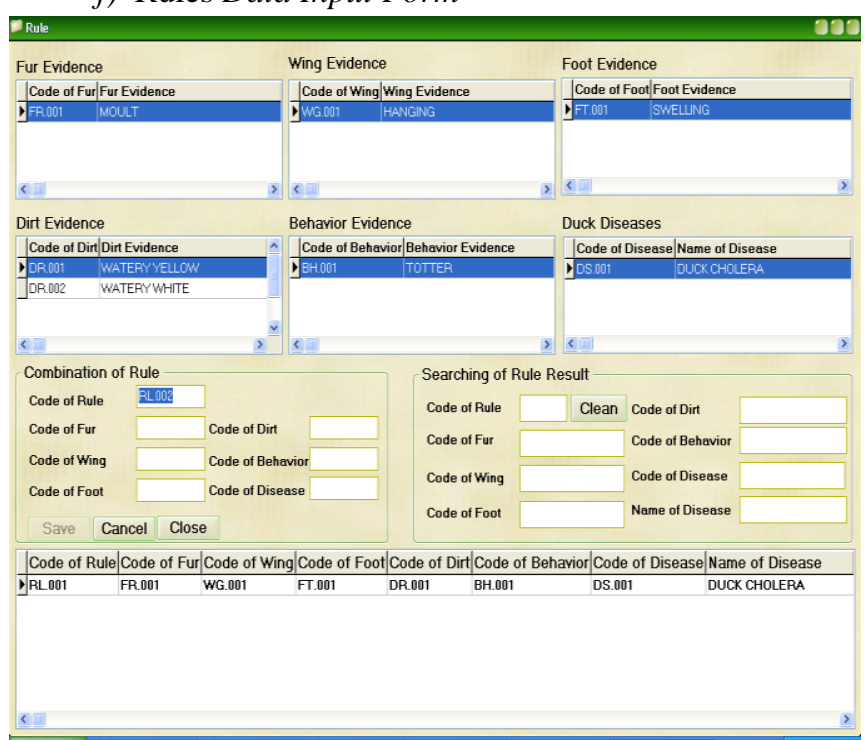

Fig. 10. Rules Data Input Form

This rules data input form is used to make symptoms combination (behaviour and physical) which is input into a order so that give an conclusion of duck disease name.

\section{g) Weight Data Input Form}

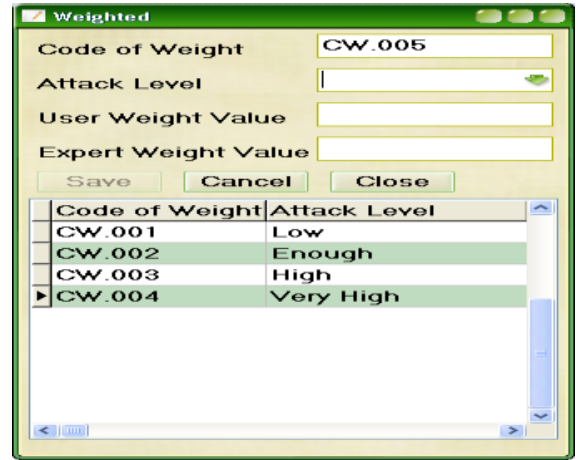

Fig. 11. Weight Data Input Form 
This weight data input form is used to make attack level weight value given by user as well as by is expert.

h) Form of Consultancy With Alliace Method

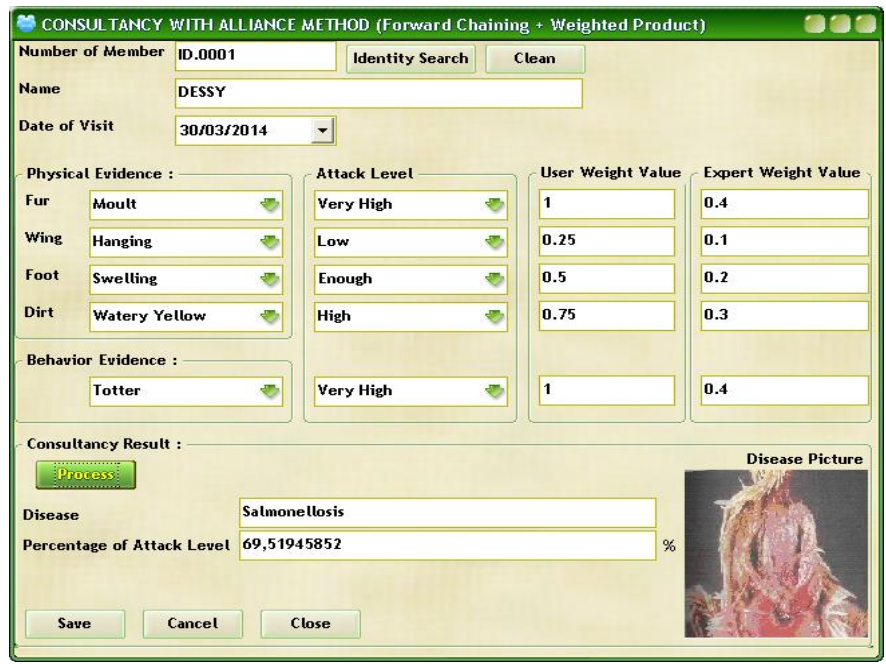

Fig. 12. Form of Consultancy With Alliace Method

This form of consultancy with alliace method is owning facility seeking of disease pursuant to physical and behaviour duck symptoms by applying forward and backward chaining concept. While concept of weighted product used to determine attack level to every physical and behavior duck symptoms. The attack level used to determine user and expert weight value, is so that obtained by attack level percentage of duck diseases with correct calculation.

\section{CONCLUSIONS}

Based on the analysis that has been made and the results of the discussion in the previous section, then some conclusions can be drawn as follows:

a) Expert systems are applied at Bali Provincial Livestock Office to facilitate duck breeders in acquiring knowledge and information about duck diseases.

b) Expert systems are applied at Bali Provincial Livestock Office has been able to provide information in accordance with the rules of alliance method. This has been proven in testing the suitability of alliance method with the calculation method of the weighted percentage of respondents at $100 \%$.

c) With usage of this expert system, can solve problems faced at Bali Provincial Livestock Office in the case gift of service to society, specially duck breeders which searching duck diseases information and also the way of solution technique. d) Expert system which woke up can fulfill fundamental characteristic of computerization system which concerning information quality, user interface, and technical ability compared to which is manual.

e) This duck diseases expert system can solve an problem of complicated become easier overcome.

f) With existence of this duck diseases expert system, user can find accurate solution or information about duck diseases.

g) At this expert system, every symptoms, diseases, and solution can be added, edited and deleted.

\section{ACKNOWLEDGMENTS}

The authors express their gratefulness to staff Bali Provincial Livestock Office for inspiring words and allowing them to use the examination data. They generously thank Mr. Dayung, President of Indonesia Technology University, and Mr. Semadi, Dean of Computer Faculty, Indonesia Technology University.

\section{REFERENCES}

[1] J.C. Giarratano, and G. Riley, Expert Systems : Principles and Programming $4^{\text {th }}$ Edition. USA : PWS Publishing Co, 2004.

[2] E. Turban, and J. E. Aronson, Decision Support Systems and Intelligent System. NJ, USA: Prentice-Hall Inc, 2001.

[3] Y. Qu, F. Tao, and H. Qui, “A Fuzzy Expert System Framework Using Object Oriented Techniques," in IEEE Pacific-Asia Workshop on Computational Intelligence and Industrial Application, 2008, pp. 474477.

[4] A. A. Hopgood, Intelligent Systems for Engineers and Scientists $\left(2^{\text {nd }}\right.$ Edition). USA : CRC Press, 2001.

[5] S.Kusumadewi, Artificial Intelligence (Technique and Application) $1^{\text {st }}$ Edition. Yogyakarta : Graha Ilmu, 2003.

[6] S. Kusumadewi, S. Hartati, A. Harjoko, and R. Wardoyo, Fuzzy Multi Attribute Decision Making (FUZZY MADM). Yogyakarta : Graha Ilmu, 2006.

[7] H. Divayana, Development of Duck Diseases Expert System with Applying Alliance Method at Bali Provincial Livestock Office. USA : Corllins University, 2014.

\section{AUTHORS BIOGRAPHY}

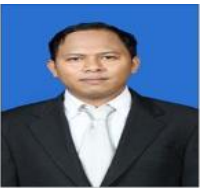

Dewa Gede Hendra Divayana, Ph.D. was born in Denpasar, Bali, in 1984. He received the B.IT degree in Information Technology in 2008, M.IT degree in Information Technology in 2010 and in 2014, he received his Ph.D. in Information Technology from Corllins University, USA. From September 2009 until now, he worked as Lecturer of Information Technology, Chair of Information Technology Department, Faculty of Computer, Indonesia Technology University, Bali, Indonesia. His research interests include Expert Systems, Artificial Intelligence, and Object Oriented Programming. 